\section{SAT0060 CHOLESTEROL SEQUESTERING IN MACROPHAGES CONTRIBUTES TO THE LIPID PARADOX IN CHRONIC ARTHRITIS}

Sandra Pérez-Baos ${ }^{1}$, Junko Arakawa ${ }^{2}$, Raquel Largo-Carazo ${ }^{1}$, Katsunori lkewaki $^{2}$, Gabriel Herrero-Beaumont'. 'Bone and Joint Research Unit, Rheumatology Dept., IIS-Fundación Jiménez Díaz UAM, Madrid, Spain; ${ }^{2}$ Division of Anti-aging and Vascular Medicine, Internal Medicine Dept., National Defense Medical College, Tokorozawa, Japan

Background: Patients with active rheumatoid arthritis (RA) have increased cardiovascular mortality, paradoxically associated with reduced circulating lipid levels (1-3). Several disease-modifying antirheumatic drugs (DMARDs), such as the JAK inhibitor tofacitinib, ameliorate disease activity along with an increase in serum lipids $(4,5)$. We previously demonstrated in vitro that tofacitinib favored cholesterol efflux from macrophages through an ABCA1-dependent mechanism (6). Furthermore, tofacitinibtreated chronic arthritic rabbits showed increased circulating lipids and decreased lipid accumulation within the synovium (6).

Objectives: Our aim was to explore in vivo whether inflammation impedes cholesterol efflux from macrophages, and whether tofacitinib restores macrophage cholesterol release during chronic arthritis. For that purpose, we assessed the ability of intraperitoneally-injected ${ }^{3} \mathrm{H}$-cholesterol labelled macrophages to efflux cholesterol to circulating lipoproteins in collageninduced arthritis (CIA) mice treated with tofacitinib or placebo, as compared to healthy controls.

Methods: DBA/1J mice were randomly assigned to healthy controls (Control, $\mathrm{n}=9), \mathrm{ClA}(\mathrm{ClA}, \mathrm{n}=6)$ and $\mathrm{ClA}$ mice receiving $50 \mathrm{mg} / \mathrm{kg} /$ day tofacitinib, orally, for three consecutive days, starting on day 39 after CIA induction and coinciding with disease peak (CIA+TOFA, $n=6)$. The day after, ${ }^{3} \mathrm{H}$-cholesterol labeled RAW264.7 macrophages were intraperitoneally injected into mice and tracer appearance was monitored in plasma lipoprotein subfractions, synovium, liver, bile and feces.

Results: The CIA group showed higher C-Reactive protein levels (CRP, $\mu \mathrm{g} / \mathrm{ml}$; Control: $10.90 \pm 0.49$, ClA: $13.86 \pm 1.05, \quad p=0.03$ vs. Control) and lower circulating ${ }^{3} \mathrm{H}$-cholesterol levels (\% of injected disintegrations per minute $(\mathrm{dpm}) / \mathrm{ml}$; Control: $1.29 \pm 0.11, \mathrm{ClA}: 0.92 \pm 0.11, \mathrm{p}=0.04$ vs. Control). Both serum CRP and ${ }^{3} \mathrm{H}$-cholesterol -particularly the $\mathrm{HDL}$ fraction- were restored to baseline after the treatment with the JAK inhibitor (CIA +TOFA: $10.97 \pm 0.67 \mu \mathrm{g} / \mathrm{ml}$ and $1.37 \pm 0.20 \%$ of injected $\mathrm{dpm} / \mathrm{ml}$, respectively, $\mathrm{p}=0.05$ vs. $\mathrm{CIA}$ ). Concomitantly, we observed an upward trend in ${ }^{3} \mathrm{H}$-cholesterol accumulation within the synovium of CIA animals as compared to controls, which tended to normalize with the treatment.

Conclusion: Systemic inflammation induces cholesterol sequestering within macrophages in vivo by acting on cholesterol efflux transporters (6). Tofacitinib favors cholesterol release to plasma lipoproteins, hence increasing circulating cholesterol. This is not only due to a decrease in inflammation -an effect very likely shared with some other biologic DMARDs-, but also to a direct mechanism on ABCA1 transporters that favors cholesterol efflux. To our knowledge, this is the first report suggesting that cholesterol dynamics in the macrophage may contribute to the overall circulating cholesterol levels, especially considering that this phenomenon may occur in other cell types, such as adipocytes.

\section{REFERENCES}

[1] Johnsson H. et al. Ann Rheum Dis. 2013;73:1495-9.

[2] Myasoedova E. et al. Ann Rheum Dis. 2012;70:482-7.

[3] Choy E, Sattar N. Ann Rheum Dis. 2009;68:460-9.

[4] Charles-Schoeman C. et al. Semin Arthritis Rheum. 2016;46:71-80.

[5] Robertson J. et al. Nat Rev Rheumatol. 2013;9:513-23.

[6] Pérez-Baos S. et al. Br J Pharmacol. 2017;174:3018-31.

Disclosure of Interests: None declared

DOI: 10.1136/annrheumdis-2019-eular.4318

\section{SAT0061 IMPORTANT ROLE OF CD11C+ CELLSIN INFLAMMATORY ARTHRITIS}

Antonia Puchner ${ }^{1}$, Elisabeth Simader ${ }^{1}$, Victoria Saferding ${ }^{1}$, Gerhard Krönke ${ }^{2}$, Rene Pfeifle', Daniel Aletaha ${ }^{1}$, Josef S. Smolen ${ }^{1}$, Stephan Blüml' ${ }^{1}{ }^{1}$ Medical University Vienna, Internal Medicine III, Vienna, Austria; ${ }^{2}$ Medical University Erlangen, Erlangen, Germany

Background: Dendritic cells (DCs) are important antigen presenting cells (APCs) and therefore they play an important role in bridging the innate and the adaptive immune response. DCs can be divided in different subsets with specific functions. As powerful APCs, DCs are thought to play an important role in the induction of autoimmune diseases such as rheumatoid arthritis. However, the active role of DCs in joint inflammation is not known yet.

Objectives: Investigation of the role of DCs cells in joint inflammation and destruction.

Methods: We analyzed histological sections of $\mathrm{K} / \mathrm{BxN}$ serum transfer arthritis as well as hTNFtg arthritis for the presence of CD11C+ cells by immunohistochemistry. We used CD11c-diphteria toxin receptor (DTR) transgenic mice. $\mathrm{K} / \mathrm{BxN}$ serum transfer arthritis was induced, and mice were given either DT or PBS or in wt and BARF3 deficient mice. In addition CD11C DTR mice were crossed into hTNFtg animals and also received either DT or PBS. The severity of arthritis was determined clinically and histologically.

Results: Both $C D 8+C D 11 c+$ and $C D 11 b+C D 11 c+$, can be found in synovial tissue in TNF driven arthritis. Upon depletion of CD11C+ cells clinical signs of $\mathrm{K} / \mathrm{BxN}$ serum transfer arthritis were significantly reduced. Histological analysis found reduced synovial inflammation after the depletion of $\mathrm{CD} 11 \mathrm{C}+$ cells in $\mathrm{K} / \mathrm{BxN}$ arthritis. In addition, local bone destruction and the number of osteoclasts was also significantly reduced. In addition to $\mathrm{K} / \mathrm{BxN}$ arthritis, we found that also in TNF-driven arthritis depletion of $\mathrm{CD} 11 \mathrm{c}+$ cells led to a striking reduction of synovial inflammation and a complete depletion of osteoclasts.

Conclusion: These data show that in addition to initiating an adaptive immune response, CD11c+ dendritic cells, are also involved in innate effector mechanisms of inflammatory arthritis. Especially $C D 11 b+C D 11 c+$ and monocyte derived inflammatory seem to play a role in inflammatory arthritis, suggesting that they could be an important therapeutic target.

Disclosure of Interests: Antonia Puchner: None declared, Elisabeth Simader: None declared, Victoria Saferding: None declared, Gerhard Krönke Grant/research support from: Lilly, Pfizer, Speakers bureau: Novartis, Rene Pfeifle: None declared, Daniel Aletaha Grant/research support from: AbbVie, Bristol-Myers Squibb, and MSD, Consultant for: AbbVie, Bristol-Myers Squibb, Eli Lilly, Janssen, Medac, Merck, MSD, Pfizer Inc, Roche, and UCB, Speakers bureau: AbbVie, Bristol-Myers Squibb, El Lilly, Janssen, Medac, Merck, MSD, Pfizer Inc, Roche, and UCB, Josef S. Smolen Grant/research support from: AbbVie, Eli Lilly, Janssen, MSD, Pfizer, Roche, Consultant for: AbbVie, Amgen, Astra-Zeneca, Astro, Celgene Corporation, Celtrion, Eli Lilly, Glaxo, ILTOO, Janssen, Medlmmune, MSD, Novartis, Pfizer, Roche, Samsun, Sanofi, UDB, Speakers bureau: AbbVie, Amgen, Astra-Zeneca, Astro, Celgene Corporation, Celtrion, Eli Lilly, Glaxo, ILTOO, Janssen, Medlmmune, MSD, Novartis, Pfizer, Roche, Samsun, Sanofi, UDB, Stephan Blüml: None declared DOI: 10.1136/annrheumdis-2019-eular.6534

\section{SAT0062 STRATIFIED MEDICINE FOR RHEUMATOID ARTHRITIS: PREDICTING RESPONSE TO BIOLOGIC THERAPY USING IMMUNE CELL SIGNATURES}

Gemma Radley ${ }^{1}$, Ben Mulhearn ${ }^{1,2}$, Laura Donlin ${ }^{3}$, Jennifer H. Anolik ${ }^{4}$, Michael Brenner ${ }^{5}$, Soumya Raychaudhuri ${ }^{1,5}$, Kimme Hyrich $^{6}$, Ann Morgan ${ }^{7}$ Gerry Wilson ${ }^{8}$, John Isaacs ${ }^{9}$, Tracy Hussell ${ }^{2}$, Anne Barton ${ }^{1}$, Sebastien Viatte' ${ }^{1}$ University of Manchester, Arthritis Research UK Centre for Genetics and Genomics, Manchester, United Kingdom² University of Manchester, Manchester Collaborative Centre for Inflammation Research, Manchester, United Kingdom ${ }^{3}$ Weill Cornell Medical College, Department of Medicine, New York, NY, United States of America; ${ }^{4}$ University of Rochester, Department of Medicine, Rochester, NY, United States of America; ${ }^{5}$ Brigham and Women's Hospital and Harvard Medical School, Boston, MA, United States of America; ${ }^{6}$ University of Manchester, Arthritis Research UK Centre for Epidemiology, Manchester, United Kingdom ${ }^{7}$ Chapel Allerton Hospital, NIHR Leeds Musculoskeletal Biomedical Research Unit, Leeds, United Kingdom; ${ }^{8}$ University College Dublin, Conway Institute of Biomolecular and Biomedical Research, Dublin, Ireland; ${ }^{9}$ Newcastleupon-Tyne Hospitals NHS Foundation Trust and Newcastle University, Newcastleupon-Tyne, United Kingdom

Background: Treatment selection of biologic therapy for patients with rheumatoid arthritis (RA) is currently a trial and error process, with approximately $40 \%$ failing to respond well to the first biologic. The lack of biomarkers to predict treatment response leads to further pain, joint damage, patient anxiety and is cost ineffective for those who are nonresponders.

Objectives: We aim to identify immune signatures from a pre-treatment blood test to inform the choice of treatment strategies for stratified medicine.

Methods: RA patients with active disease (DAS28 > 5.1) who failed to respond to conventional DMARDs and were due to commence biologic treatment were included in the BRAGGSS cohort. Peripheral blood mononuclear cells (PBMCs) taken before the initiation of biologic treatment were available for 300 patients (good $(60 \%)$, moderate $(25 \%)$, and non- 
responders (15\%) to various biologics (anti-TNFs (68\%), Rituximab (16\%), Tocilizumab (13\%), Abatacept $(3 \%))$. PBMCs were left unstimulated or stimulated (anti-CD3/CD28 beads or $10 \mathrm{ng} / \mathrm{mL}$ LPS) and stained with three flow cytometry panels including specific surface, intracellular and intranuclear markers to deeply characterise the function of several subsets of monocytes, NK cells, $T$ cells and B cells (e.g. disease-associated cell populations such as $\mathrm{PD}-1^{\text {hi }} \mathrm{CXCR} 5^{-}$peripheral $\mathrm{T}$ helpers (Rao DA Nature 2017), CD27 ${ }^{-} \mathrm{HLA}^{-D R^{+}}$effector $\mathrm{CD}^{+}{ }^{+} \mathrm{T}$ cells (Fonseka CY Sci Trans/ Med 2018) and cytotoxic PD $-1^{+} \mathrm{CXCR} 5^{-} \mathrm{CD}^{+} \mathrm{T}$ cell subsets, $\mathrm{T}_{\text {bet }}{ }^{+} \mathrm{CD} 11 \mathrm{c}^{+}$ autoimmune-associated $\mathrm{B}$ cells, $\mathrm{CD} 14^{+} \mathrm{IL} 1 \beta^{+}$pro-inflammatory monocytes (Zhang F BioRxiv 2018)). Hypothesis-free clustering algorithms were also used for data analysis to identify unreported cell populations. Statistical association testing was preformed using mixed effects ordinal (EULAR response) or linear (DAS28 or its components) regression models.

Results: Preliminary interim analysis identified associations between panbiologic non-response and spontaneous expression of pro-inflammatory cytokines (Th1, Th17 lineage) by $\mathrm{CD}^{+} \mathrm{T}$ cells $(\mathrm{p}<0.003)$. Good response to all biologic drugs was independently associated with the number of $\mathrm{CD}^{\mathrm{dim}} \mathrm{CD}^{\mathrm{d}}{ }^{+} \mathrm{NK}$ cells $(\mathrm{p}<0.001)$. Good response to anti-TNFs was associated with $\mathrm{TNF} \alpha$, IFN $\gamma$ and perforin producing $\mathrm{CD}^{+}{ }^{+} \mathrm{T}$ cells after in vitro stimulation with anti-CD3/CD28 $(p<0.02)$.

Conclusion: Ongoing work involves the replication of these results. The identification of immune cell types associated with response to a particular class of biologic drugs (e.g. anti-TNFs, but not other classes) might inform the choice of first line biologic drugs based on individual patients' immune profiles (stratification to treatment response categories). Cells or cytokines generally associated with non-response to all biologics could represent new therapeutic targets, at least in some patients groups.

Acknowledgement: AMP RA/SLE

Disclosure of Interests: Gemma Radley: None declared, Ben Mulhearn: None declared, Laura Donlin: None declared, Jennifer H. Anolik: None declared, Michael Brenner Grant/research support from: Roche: sponsored research agreement on stromal cells (but has nothing to do with checkpoint related disease), Consultant for: GSK: consultant. (I am part of their immunology network, a group of about 8 immunologists who advise them regularly and broadly in the areas of inflammation and infection)., Soumya Raychaudhuri: None declared, Kimme Hyrich Grant/research support from: Grants to institution: BMS, Pfizer, UCB, Ann Morgan: None declared, Gerry Wilson: None declared, John Isaacs Grant/research support from: Pfizer, Grant/research support from: Pfizer, Consultant for: Abbvie, Pfizer, Roche, Galvani, Merck, Gilead, Eli Lilly, Amgen, Janssen, Celltrion, NAPP, Consultant for: Abbvie, Pfizer, Roche, Galvani, Merck, Gilead, Eli Lilly, Amgen, Janssen, Celltrion, NAPP, Speakers bureau: Abbvie, Pfizer, Eli Lilly, Speakers bureau: Abbvie, Pfizer, Eli Lilly, Tracy Hussell: None declared, Anne Barton: None declared, Sebastien Viatte: None declared DOI: 10.1136/annrheumdis-2019-eular.2371

\section{SAT0063 ASSOCIATION OF SMOKING WITH TRIPLE CONCORDANT SEROPOSITIVITY IN RA PATIENTS, AND WITH RHEUMATOID FACTOR IN THE REMAINING PATIENTS}

Cristina Regueiro ${ }^{1}$, Luis Rodriguez Rodriguez² ${ }^{2}$, Raquel López-Mejías ${ }^{3}$,

Laura Nuño ${ }^{4}$, Ana Triguero-Martinez ${ }^{5}$, Eva Perez-Pampín ${ }^{1}$, Alfonso Corrales ${ }^{3}$, Alejandro Villalva ${ }^{4}$, Yolanda Lopez-Golan ${ }^{1}$, Lydia Abasolo ${ }^{2}$, Sara Remuzgo Martinez ${ }^{3}$, Ana Ortiz ${ }^{5}$, Eva Herranz ${ }^{2}$,Ana Martínez-Feito ${ }^{4}$,

Carmen Conde ${ }^{1}$, Antonio Mera Varela ${ }^{1}$,Alejandro Balsa ${ }^{4}$, Isidoro GonzálezÁlvaro ${ }^{5}$, Miguel A. González-Gay ${ }^{3}$, Benjamin Fernandez ${ }^{2}$,Antonio Gonzalez ${ }^{1}$. ${ }^{1}$ Insituto de Investigacion Sanitaria - Hospital Clinico Universitario de Santiago, Santiago de Compostela, Spain; ${ }^{2}$ Insituto de Investigacion Sanitaria San Carlos, Madrid, Spain; ${ }^{3}$ Hospital de Investigacion Sanitaria Valdecilla, Santander, Spain; ${ }^{4}$ Insituto de Investigacion del Hospital Universitario La Paz, Madrid, Spain; ${ }^{5}$ Insituto de Investigacion del Hospital de La Princesa, Madrid, Spain

Background: The contribution of cigarette smoking to the risk of rheumatoid arthritis (RA) is larger for seropositive than for seronegative patients. Current pathogenic models explain this difference via the production of anti-citrullinated protein antibodies (ACPA) induced by protein citrullination in the lungs as a consequence of smoking. However, there are inconsistent results with this model including the van Wesemael et al. report, which found an association of smoking with the concurrent presence of ACPA, rheumatoid factor (RF) and anti-carbamylated protein antibodies (ACarPA), rather than with ACPA.

Objectives: We aimed to explore the relationship between smoking and the presence of FR, ACPA and ACarPA and their combinations in patients with RA.

Methods: Six cohorts with 2253 RA patients were obtained to replicate the van Wesemael et al. results. After replication, they were combined with the three cohorts from that study comprising 2238 patients to a total of 4491 patients. The results from the different cohorts were combined by fixed-effects meta-analysis. Most analyses involved comparisons between two levels of smoking exposure, never and ever smokers, considering the $\mathrm{RF}^{-} / \mathrm{ACPA}^{-} / \mathrm{ACarP}^{-}$patients as the reference.

Results: Analysis of the replication set confirmed the predominant association of smoking with the concurrent presence of the three RA autoantibodies $\left(\mathrm{OR}=1.99, \mathrm{P}=2.5 \times 10^{-8}\right)$, whereas the patients with one or two antibodies were not different from the patients without antibodies (OR $=1.22, \mathrm{p}=0.4$ and $\mathrm{OR}=1.22, \mathrm{p}=0.3$, respectively). The combined meta-analysis with all the cohorts clarified the dominant association of smoking with the triple concordant seropositivity $(O R=2.00, p=4.4 x$ $\left.10^{-16}\right)$. In contrast, there was no association with the patient bearing one autoantibody $(\mathrm{OR}=1.12, \mathrm{p}=0.4)$, and an in-between association with the concurrent presence of two antibodies ( $O R=1.26, p=0.009$ ). More over, the association with the presence of three antibodies was significantly larger than with two antibodies (OR $=1.54, \mathrm{p}=1.4 \times 10^{-6}$ ), whereas the association with the presence of two antibodies was not larger than with one autoantibody $(O R=1.11, p=0.3)$. In the patients remaining after exclusion of the triple seropositive, the smokers were exclusively associated with the $\mathrm{RF}^{+}(\mathrm{OR}=1.28, \mathrm{p}=0.03$ and $\mathrm{OR}=$ $1.30, p=0.004$ in the double and single positive patients, respectively) This association was independent of the reference, either the triple seronegative $(O R=1.29, p=0.001)$ or all the RF-patients $(O R=1.32, p=$ 0.0002).

Conclusion: Smoking increases RA susceptibility by promoting pathways leading to the concurrent presence of the three RA autoantibodies and, in its defect, to the production of RF. These actions are not covered by current pathogenic models and suggest that smoking accelerates epitope spreading.

\section{REFERENCE}

[1] van Wesemael, et al. Arthritis Res Ther. 2016;18:285.

Acknowledgement: Supported by grants PI17/01606 and RD16/0012/0014 of the Instituto de Salud Carlos III (Spain) that are partially financed by FEDER.

Disclosure of Interests: Cristina Regueiro : None declared, Luis Rodriguez Rodriguez: None declared, Raquel López-Mejías: None declared, Laura Nuño: None declared, Ana Triguero-Martinez: None declared, Eva PerezPampín: None declared, Alfonso Corrales: None declared, Alejandro Villalva: None declared, Yolanda Lopez-Golan: None declared, Lydia Abasolo: None declared, Sara Remuzgo Martinez: None declared, Ana Ortiz: None declared, Eva Herranz: None declared, ANA MARTÍNEZ-FEITO: None declared, Carmen Conde : None declared, ANTONIO MERA VAR ELA: None declared, Alejandro Balsa Grant/research support from: Abbvie, Pfizer, Novartis, BMS, Nordic, Sanofi, Consultant for: Abbvie, Pfizer, Novartis, BMS, Nordic, Sanofi, Sandoz, Lilly, Paid instructor for: Pfizer, Speakers bureau: Pfizer, Novartis, UCB, Nordic, Sanofi, Sandoz, Lilly, Isidoro González-Álvaro: None declared, Miguel A González-Gay Grant research support from: Prof. MA Gonzalez-Gay received grants/research supports from Abbvie, MSD, Jansen and Roche., Speakers bureau: Consultation fees/participation in company sponsored speaker's bureau from Pfizer, Lilly, Sobi, Celgene, Novartis, Roche and Sanofi., Benjamin Fernandez: None declared, Antonio Gonzalez: None declared DOI: 10.1136/annrheumdis-2019-eular.4607

\section{SAT0064 EXPANSION OF CD16+ MONOCYTE SUBSETS AND ACE EXPRESSION ARE ASSOCIATED WITH ARTERIAL THICKENING AND VASCULAR FUNCTION IN VERY EARLY RHEUMATOID ARTHRITIS}

Javier Rodríguez-Carrio ${ }^{1,2}$, Mercedes Alperi-López ${ }^{3}$, Patricia López ${ }^{1}$, Ángel PérezÁlvarez ${ }^{4}$, Lorena Benavente ${ }^{4}$, Francisco Javier Ballina-García ${ }^{3}$, Ana Suárez ${ }^{1}$. ${ }^{1}$ University of Oviedo, ISPA, Area of Immunology, Oviedo, Spain; ${ }^{2}$ Hospital Universitario Central de Asturias, Bone and Mineral Research Unit, Instituto Reina Sofía de Investigación Nefrológica, REDinREN del ISCIII, Oviedo, Spain; ${ }^{3} \mathrm{Hospital}$ Universitario Central de Asturias, Department of Rheumatology, Oviedo, Spain; ${ }^{4}$ Hospital Universitario Central de Asturias, Department of Neurology, Oviedo, Spain

Background: monocytes are largely recognized as drivers of the atherosclerosis development, the leading determinant of cardiovascular (CV) morbidity in rheumatoid arthritis (RA). Far from being a unique population, functionally and phenotypically subpopulations can be distinguished although their relevance to CV disease is uncertain. Recently, the expression of angiotensin-converting enzyme (ACE) expression has been 